Jud, G. D., Wingler, T. R.., and D. T. Winkler. "Single-Family Housing and Wealth Portfolios.” Journal of Real Estate Portfolio Management, vol. 12, no. 1, 2006, pp. 13-22. Made available courtesy of American Real Estate Society: http://www.aresnet.org/

***Reprinted with permission. No further reproduction is authorized without written permission from the American Real Estate Society.

This version of the document is not the version of record. Figures and/or pictures may be missing from this format of the document.***

\title{
Single-Family Housing and Wealth Portfolios
}

Executive Summary. This paper explores the risk and return of a portfolio of single-family housing during 1978:1-2001:4 in the context of a portfolio of financial assets. Homeownership offers higher returns to those who have higher tax brackets, longer investment horizons and use more financial leverage. Housing returns are positively correlated with large-stock returns and negatively correlated with returns on small stocks and debt securities. Portfolio allocation to housing is large in a minimum variance portfolio, and it increases with longer holding periods and higher tax brackets. Homeownership risk and return vary widely among the fortytwo MSAs studied, and within an MSA, housing returns exhibit substantial variation.
*University of North Carolina-Greensboro, Greensboro, NC 27412-5001 or juddon@uncg.edu.

**University of North Carolina-Greensboro, Greensboro, NC 27412-5001 or tony_wingler@uncg.edu.

$\star \star \star$ University of North Carolina-Greensboro, Greensboro, NC 27412-5001 or dtwinkler@uncg.edu. by G. Donald Jud*

Tony R. Wingler**

Daniel T. Winkler***

\section{Introduction}

According to the Federal Reserve's 2001 Survey of Consumer Finance, $68 \%$ of the nation's households are homeowners, and the average homeowner household has $28.5 \%$ of its total assets invested in its primary residence. On average, homeowner households have an equity interest equal to $49.3 \%$ of the market value of their primary residence. The large financial investment in homeownership has important implications for household portfolio return and risk.

Modern portfolio theory would suggest that an individual should not put such a large percentage of one's wealth in a single housing asset because of substantial unsystematic risk that could otherwise be eliminated. ${ }^{1}$ While a large stock mutual fund can eliminate almost all unsystematic risk, there has been no such effective method of diversification in single-family housing. However, there is evidence that this could change because of recent proposals for the development of housing partnerships, as well as housing futures contracts. ${ }^{2}$

Caplin, Sewin, Freeman and Tracy (1997) have proposed the development of a primary market in housing limited partnerships, and also, a national secondary market in limited partnerships. In a typical housing partnership, an institutional investor would hold a portion of the equity capital in a house. The homeowner would be a managing partner while the financial institution would be the limited partner. Caplin (1999) has noted that the prospects for the development of these markets are quite good, because costs of market development have fallen and the need of homeowners to transfer this risk is high. ${ }^{3}$ 
The purpose of this study is to examine the returns and risk of a diversified portfolio of single-family houses for 3-, 5- and 10-year holding periods and to explore the combination of housing with other financial assets to form an efficient investment frontier. The allocation of the national housing portfolio in the efficient set is investigated; the allocation question also is conducted assuming housing portfolio investment in five metropolitan areas.

The perspective of this study is a portfolio of single-family, owner-occupied housing. A diversified single-family housing portfolio might be held by individuals who hold multiple rental properties, institutional investors who decide to hold foreclosed properties, and likely in the near future, a diversified limited partnership interest. ${ }^{4}$ The approach used here also provides some insight into risk and return from investing in housing futures contracts when these become available.

The return calculations consider the impact of the following: (1) home price appreciation; (2) the imputed rental value of the dwelling unit; (3) income tax rates; (4) mortgage leverage; (5) transaction costs; (6) insurance and maintenance expenses; and (7) property taxes. ${ }^{5}$ A notable shortcoming in past studies is the neglect of the importance of the refinancing option in the traditional fixed-rate home mortgage. During periods of falling interest rates, the ability to refinance is likely to generate substantial equity gains for homeowners. In the analysis that follows, the refinancing option is explicitly considered. In addition, many studies exclude the effects of transaction costs in residential real housing, which are usually quite large by standards of financial asset markets. The housing returns and risk are examined at the national and metropolitan levels, including many revenues and expenses often ignored in prior research.

\section{Literature}

A number of studies have examined the risks and returns of housing market investment, including papers by Coyne, Goulet and Picconi (1980), Alberts and Kerr (1981), Hendershott and Hu (1981), Peiser and Smith (1985), Webb and Rubens (1987), Miller and Sklarz (1989), Case and Shiller (1990),
Ermer, Cassidy, and Sullivan (1994) and Harris (2002).

Several studies have portfolio allocation models for single-family housing and other assets where housing returns are based on individual houses. Goetzmann (1993) finds that the minimum risk portfolio would typically allocate about $50 \%$ to home investment and that investing in an individual house has about twice the risk of a welldiversified housing portfolio. Englund, Hwang and Quigley (2002) study single-family housing returns in Stockholm Sweden from January 1981 to August 1993. Their results indicate that an efficient portfolio would include no housing for short holding periods, but for longer periods, low-risk portfolios would include between $15 \%$ and $50 \%$ housing. Flavin and Yamashita (2002) find that young households are forced to have a large amount of real estate relative to their net worth and have a strong incentive to pay down their mortgage. The efficient frontier depends on the level of risk aversion and age of the household. Eichholtz, Koedijk and de Roon (2002) use house price indexes from Shiller, Case and Weiss (1993) and a meanvariance framework to examine residential property holdings. They find that residential real estate offers significant diversification benefits and that most investors in the United States have the optimal diversification benefits by allocating about $30 \%$ of their investment portfolio to residential real estate.

\section{A Model of Investment Returns}

A first step in the estimation of the efficient frontier of multi-asset portfolios including singlefamily housing is the measurement of housing investment returns. The returns to homeownership stem from the implicit savings of rental expenses, as well as capital gains arising from housing price appreciation. On the expense side, homeowners incur costs from the payment of mortgage interest, property taxes, and insurance and maintenance. High transaction costs are incurred when a homeowner buys or sells a residence. The transaction costs are expected to have a significant impact on shorter-term holding periods, and a lesser effect over the longer-term. The returns to homeownership are measured using the internal rate of return 
model (Miller and Sklarz, 1989). This equation is written as follows:

$$
I C O_{0}=\sum_{t=1}^{n} \frac{A C F_{t}}{(1+r)^{t}}+\frac{E P R_{n}}{(1+r)^{n}}
$$

Where:

$r=$ The after-tax IRR;

$I C O_{0}=$ The initial cash outflow at time 0 , where $I C O_{0}=$ PPrice $(1-l v r)+I F$

$I F=$ Initial fees;

$l v r=$ Leverage ratio (ratio of mortgage to house value);

$A C F_{t}=$ Annual cash flows in period $t$, where $A C F_{t}=I R_{t}-P P_{t}-I P_{t}(1-t r)-P T_{t}$ $(1-t r)-M C_{t}$;

$I R_{t}=$ Imputed gross rent in period $t$;

$I P_{t}=$ Interest payment in period $t$

$M C_{t}=$ Maintenance and insurance costs in period $t$;

$P P_{t}=$ Principal payment in period $t$;

PPrice $=$ Purchase price;

$P T_{t}=$ Property tax in period $t$;

$t r=$ Income tax rate;

$E P R_{n}=$ The end-of-period return at time $n$, where $E P R_{n}=S P-M B_{n}-T F$;

$M B_{n}=$ Mortgage balance in period $n$;

$S P=$ Sales price; and

$T F=$ Terminal fees.

Equation (1) assumes owner-occupied, single family, rental housing returns are substantially similar. ${ }^{6}$ Therefore, the findings in this study can be generalized to a portfolio of residential rental housing.

\section{Data}

Jud and Winkler (2005) solve Equation (1) for the after-tax IRR for homeownership, employing a number of assumptions. ${ }^{7}$ First, they measure home prices using the Office of Federal Housing Enterprise Oversight (OFHEO) quality-adjusted price index for existing homes from 1978:Q1 to 2001:Q4.

Second, implicit gross rents are estimated using the Bureau of Economic Analysis (BEA) series on imputed rents for owner-occupied housing, taken from the National Income and Product Account Tables (NIPA). The imputed rent series is divided by estimates of the value of the owner-occupied housing stock, also estimated by BEA. From 1978 through 2000 , imputed rent averaged $7.7 \%$ of home value. This percentage represents the implicit gross rental return to homeownership. The rental return ranges from a high of $8.5 \%$ in 1991 to a low of $6.3 \%$ in 1979.

Third, interest cost is calculated using the monthly 30-year conventional mortgage rate series compiled by the Federal Home Mortgage Corporation. The homeowner is assumed to refinance the loan. whenever the market rate drops $2 \%$ below the initial rate and is assumed to pay a cost equal to $1.5 \%$ of the outstanding balance on the loan.

Fourth, property taxes are calculated based on data taken from the Census Bureau's American Housing Survey (AHS). On the basis of AHS data for 1993 and 1999, property taxes are assumed to be $1.06 \%$ of housing value annually. ${ }^{8}$

Lastly, maintenance and insurance costs also are calculated using estimates from AHS data. Based on AHS data for 1993 and 1999, the average homeowner is estimated to spend $0.72 \%$ of the value of the home on maintenance and insurance. In the housing market, transaction costs are not trivial and their effect on returns cannot be ignored. Initial fees and charges are assumed to be $2 \%$ of the purchase price, and terminal fees are assumed to be $6 \%$ of the sales price. ${ }^{9}$

\section{Empirical Results}

\section{Investment Returns Using a National Housing Portfolio}

Exhibit 1 ( $a$ and $b$ ) shows the returns to homeownership tabulated by Jud and Winkler (2005), employing Equation (1) and the OFHEO national price index series. A series of holding period returns are presented beginning in 1978:Q1 and computing all possible 3-, 5- and 10-year holding periods to 2001:Q4. Average returns and standard deviations are presented for various tax rates and loan-to-value ratios. 


\section{Exhibit 1 a}

Average Holding Period Returns and Risks to Homeownership

$15 \%$ Marginal Tax Rate

\begin{tabular}{|c|c|c|c|c|c|}
\hline & \multicolumn{5}{|l|}{$\mathrm{L} / \mathrm{V}$} \\
\hline & $0 \%$ & $70 \%$ & $80 \%$ & $90 \%$ & $95 \%$ \\
\hline \multicolumn{6}{|c|}{ Panel A: 3-Year Holding Period $\{n=85\}$} \\
\hline Mean & $7.79 \%$ & $6.77 \%$ & $5.85 \%$ & $3.79 \%$ & $1.47 \%$ \\
\hline Std. Dev. & $1.85 \%$ & $6.99 \%$ & $10.08 \%$ & $16.74 \%$ & $24.13 \%$ \\
\hline C.V. & 0.24 & 1.03 & 1.72 & 4.41 & 16.45 \\
\hline Min. & $5.50 \%$ & $-7.60 \%$ & $-15.46 \%$ & $-31.61 \%$ & $-47.79 \%$ \\
\hline Max. & $12.18 \%$ & $20.84 \%$ & $25.99 \%$ & $36.94 \%$ & $49.25 \%$ \\
\hline Median & $7.09 \%$ & $6.87 \%$ & $6.38 \%$ & $5.17 \%$ & $3.52 \%$ \\
\hline \multicolumn{6}{|c|}{ Panel B: 5-Year Holding Period $(n=77)$} \\
\hline Mean & $9.34 \%$ & $9.61 \%$ & $9.75 \%$ & $10.04 \%$ & $10.39 \%$ \\
\hline Std. Dev. & $1.43 \%$ & $4.26 \%$ & $5.88 \%$ & $9.00 \%$ & $11.96 \%$ \\
\hline C.V. & 0.15 & 0.44 & 0.60 & 0.90 & 1.15 \\
\hline Min. & $6.73 \%$ & $2.24 \%$ & $-1.00 \%$ & $-6.59 \%$ & $-11.12 \%$ \\
\hline Max. & $11.79 \%$ & $18.17 \%$ & $21.52 \%$ & $27.93 \%$ & $34.23 \%$ \\
\hline Median & $9.15 \%$ & $9.50 \%$ & $9.74 \%$ & $11.01 \%$ & $11.50 \%$ \\
\hline \multicolumn{6}{|c|}{ Panel C: 10-Year Holding Period $(n=56)$} \\
\hline Mean & $10.17 \%$ & $11.29 \%$ & $11.76 \%$ & $12.52 \%$ & $13.14 \%$ \\
\hline Std. Dev. & $0.84 \%$ & $1.64 \%$ & $2.11 \%$ & $2.92 \%$ & $3.57 \%$ \\
\hline C.V. & 0.08 & 0.14 & 0.18 & 0.23 & 0.27 \\
\hline Min. & $8.74 \%$ & $8.53 \%$ & $7.88 \%$ & $6.96 \%$ & $6.35 \%$ \\
\hline Max. & $12.04 \%$ & $16.30 \%$ & $17.88 \%$ & $20.35 \%$ & $22.26 \%$ \\
\hline Median & $10.42 \%$ & $11.19 \%$ & $11.51 \%$ & $12.10 \%$ & $12.64 \%$ \\
\hline
\end{tabular}

The findings in Exhibit 1 indicate that longer holding periods are associated with higher average returns and lower risk, where risk is measured by the standard deviation in returns or the coefficient of variation (C.V.). This is because longer holding periods reduce the per-period effect of transaction costs by spreading these costs over longer time periods. Longer holding periods do reduce interestrate tax subsidy (as the interest tax shield decreases over time), but high housing transactions costs make it more profitable to have a longer holding period even though the interest tax shield diminishes with longer holding periods.

The effect of leverage on the rate of return and risk varies with the personal tax rate. As shown in Exhibit 1, homeowners in the 15\% marginal tax
Exhibit 1 b

Average Holding Period Returns and Risks to Homeownership 28\% Marginal Tax Rate

\begin{tabular}{lllll}
\hline LN & & & & \\
\hline $0 \%$ & $70 \%$ & $80 \%$ & $90 \%$ & $95 \%$ \\
\hline
\end{tabular}

\begin{tabular}{lccccc}
\hline Panel A: 3 -Year Holding Period $(n=85)$ & & & \\
\hline Mean & $8.48 \%$ & $9.87 \%$ & $10.62 \%$ & $12.22 \%$ & $14.06 \%$ \\
Std. Dev. & $1.86 \%$ & $6.60 \%$ & $9.47 \%$ & $15.83 \%$ & $23.24 \%$ \\
C.V. & 0.22 & 0.67 & 0.89 & 1.30 & 1.65 \\
Min. & $5.65 \%$ & $-3.30 \%$ & $-9.09 \%$ & $-21.56 \%$ & $-35.03 \%$ \\
Max. & $12.34 \%$ & $23.06 \%$ & $29.43 \%$ & $43.55 \%$ & $60.31 \%$ \\
Median & $8.03 \%$ & $9.53 \%$ & $10.80 \%$ & $13.30 \%$ & $16.82 \%$
\end{tabular}

Panel B: 5-Year Holding Period $(n=77)$

\begin{tabular}{lccccc}
\hline Mean & $9.48 \%$ & $12.39 \%$ & $13.87 \%$ & $16.85 \%$ & $19.97 \%$ \\
Std. Dev. & $1.43 \%$ & $3.97 \%$ & $5.44 \%$ & $8.39 \%$ & $11.43 \%$ \\
C.V. & 0.15 & 0.32 & 0.39 & 0.50 & 0.57 \\
Min. & $6.87 \%$ & $5.84 \%$ & $4.11 \%$ & $0.97 \%$ & $-1.76 \%$ \\
Max. & $11.94 \%$ & $20.32 \%$ & $24.74 \%$ & $33.49 \%$ & $42.64 \%$ \\
Median & $9.30 \%$ & $12.34 \%$ & $13.55 \%$ & $17.11 \%$ & $20.71 \%$
\end{tabular}

Panel C: 10-Year Holding Period $(n=56)$

\begin{tabular}{lccccc}
\hline Mean & $10.32 \%$ & $13.51 \%$ & $14.86 \%$ & $17.16 \%$ & $19.14 \%$ \\
Std. Dev. & $0.85 \%$ & $1.49 \%$ & $1.93 \%$ & $2.79 \%$ & $3.65 \%$ \\
C.V. & 0.08 & 0.11 & 0.13 & 0.16 & 0.19 \\
Min. & $8.89 \%$ & $11.00 \%$ & $11.17 \%$ & $11.43 \%$ & $11.62 \%$ \\
Max. & $12.20 \%$ & $18.10 \%$ & $20.41 \%$ & $24.21 \%$ & $27.39 \%$ \\
Median & $10.58 \%$ & $13.46 \%$ & $14.66 \%$ & $17.02 \%$ & $19.00 \%$
\end{tabular}

Note: The source is Jud and Winkler, 2005.

bracket investing for a 3-year holding period reduce their average return by leveraging their home investment. The non-leveraged return for this group is $7.79 \%$, but with $95 \%$ leverage, the return falls to $1.47 \%$. For all other holding periods and tax rates shown in Exhibit 1, additional leverage raises homeownership returns. ${ }^{10}$ While higher leverage does not always result in higher returns, additional leverage always raises the level of investment risk. Whether risk is measured by the standard deviation of quarterly returns or the coefficient of variation, risk increases with leverage for all of the tax-rate/holding-period combinations.

Higher marginal tax rates, of course, produce a greater subsidy to homeownership because of the deductibility of interest and property taxes and, 
thus, provide higher average returns. But higher tax rates also reduce the risk of homeownership by allowing higher-income taxpayers to pass along a greater share of their interest and property taxes to the federal government, thereby mitigating the effects of high interest rates on property returns.

Exhibit 2 compares financial market returns and inflation to homeownership returns for 5-year holding periods from 1978:Q1 to 2000:Q4 (homeownership returns are computed using a $28 \%$ marginal tax rate). Homeownership with high leverage provides returns greater than stocks, but with more risk. With 50\% leverage, the mean homeownership return is similar to longer-term treasuries and corporate bonds, but with about onethird less risk. Non-leveraged homeownership provides returns that are about equal to intermediate treasuries, but with about half the risk.

Exhibit 3 examines the correlation between 5-year holding-period, homeownership returns (calculated using a $28 \%$ marginal tax rate and various loan-to-value ratios) and financial assets and inflation. For large-cap stocks, all the correlation coefficients shown are positive and all are statistically significant at the 0.05 level. For other financial assets, the correlations with homeownership are negative in every case except for the non-leveraged return series. The negative correlation of housing returns with debt securities increases substantially with leverage.$^{11}$ For non-leveraged homeownership, the correlations are positive except for small-cap stocks.
Exhibit 3

\section{Correlation Between Homeownership and} Financial Assets: 1978:01-2001:04 (5-year holding period)

\begin{tabular}{lcccc}
\hline & \multicolumn{4}{l}{ Homes } \\
\cline { 2 - 5 } & $90 \% \mathrm{LV}$ & \multicolumn{1}{c}{$80 \% \mathrm{LV}$} & $50 \% \mathrm{LV}$ & $0 \% \mathrm{LV}$ \\
\hline S\&P 500 & $\mathbf{0 . 2 2 5}$ & $\mathbf{0 . 2 2 5}$ & $\mathbf{0 . 2 4 4}$ & $\mathbf{0 . 2 3 5}$ \\
Small Stocks & $\mathbf{- 0 . 2 3 0}$ & $-\mathbf{0 . 2 3 9}$ & $-\mathbf{0 . 2 4 8}$ & -0.206 \\
L-T Corporates & $\mathbf{- 0 . 5 1 6}$ & $\mathbf{- 0 . 4 5 5}$ & $\mathbf{- 0 . 2 3 4}$ & 0.212 \\
L-T Treasuries & $\mathbf{- 0 . 4 4 4}$ & $\mathbf{- 0 . 3 9 2}$ & -0.198 & 0.194 \\
I-T Treasuries & $\mathbf{- 0 . 6 0 4}$ & $\mathbf{- 0 . 5 2 2}$ & $\mathbf{- 0 . 2 5 1}$ & $\mathbf{0 . 2 7 6}$ \\
90-Day T-Bills & $\mathbf{- 0 . 3 3 5}$ & $\mathbf{- 0 . 2 6 0}$ & -0.043 & $\mathbf{0 . 3 3 6}$ \\
CPI & -0.197 & -0.153 & -0.051 & 0.122 \\
\hline
\end{tabular}

Note: Bold type indicates significance at the 0.05 level and above. $N=77$.

\section{Investment Returns Using a MSA Housing Portfolio}

Jud and Winkler (2005) use the OFHEO data to calculate homeownership returns for metropolitan statistical areas (MSAs). Exhibit 4 presents averages of the 5-year holding period returns for fortytwo MSAs, assuming an $80 \%$ loan-to-value ratio and a $28 \%$ marginal tax rate. For each MSA in Exhibit 4, there are seventy-seven 5-year holding periods beginning in 1978:Q1 and extending through 2001:Q4.

Substantial variation in returns across the country is reported in Exhibit 4. Returns range from a high of $19.9 \%$ in Tampa to a low of $5.3 \%$ in San Diego.

\section{Exhibit 2}

Returns to Homeownership and Financial Assets: 1978:01-2001:04 (Annual returns, 5-year holding periods)

\begin{tabular}{|c|c|c|c|c|c|c|c|c|c|c|c|}
\hline & \multicolumn{4}{|l|}{ Homes } & \multirow[b]{2}{*}{ S\&P 500} & \multirow{2}{*}{$\begin{array}{l}\text { Small } \\
\text { Stocks }\end{array}$} & \multirow{2}{*}{$\begin{array}{l}\text { Long-Term } \\
\text { Corporates }\end{array}$} & \multirow{2}{*}{$\begin{array}{l}\text { Long-Term } \\
\text { Treasuries }\end{array}$} & \multirow{2}{*}{$\begin{array}{l}\text { Intermediate } \\
\text { Treasuries }\end{array}$} & \multirow{2}{*}{$\begin{array}{l}\text { 90-Day } \\
\text { T-Bills }\end{array}$} & \multirow[b]{2}{*}{ CPI } \\
\hline & $90 \% \mathrm{LV}$ & $80 \% \mathrm{LV}$ & $50 \% \mathrm{LV}$ & $0 \% \mathrm{LV}$ & & & & & & & \\
\hline Mean & 16.85 & 13.87 & 10.89 & 9.49 & 15.97 & 14.34 & 10.84 & 11.02 & 9.51 & 6.62 & 3.91 \\
\hline Std. Dev. & 8.39 & 5.44 & 2.53 & 1.44 & 4.26 & 6.88 & 3.95 & 3.75 & 2.95 & 2.14 & 1.68 \\
\hline C.V. & 0.50 & 0.39 & 0.23 & 0.15 & 0.27 & 0.48 & 0.36 & 0.34 & 0.31 & 0.32 & 0.43 \\
\hline Minimum & 1.00 & 4.10 & 6.70 & 6.90 & 8.40 & 0.60 & 4.40 & 3.80 & 5.30 & 4.10 & 2.20 \\
\hline Maximum & 33.50 & 24.70 & 15.80 & 11.90 & 25.90 & 29.20 & 22.00 & 21.80 & 17.60 & 10.70 & 9.10 \\
\hline Median & 17.10 & 13.60 & 10.80 & 9.30 & 15.00 & 13.20 & 9.90 & 10.10 & 9.20 & 6.40 & 3.50 \\
\hline
\end{tabular}

Notes: Financial market returns and inflation computed by the authors from the Ibbotson database. Homeownership returns assume a $28 \%$ marginal tax rate. $N=77$. 


\section{Exhibit 4}

Average Returns for Five-Year Holding Periods 1978-2001

\begin{tabular}{|c|c|c|c|c|c|c|}
\hline MSA & $\begin{array}{l}\text { Mean } \\
\text { (\%) }\end{array}$ & $\begin{array}{l}\text { Std. } \\
\text { Dev. } \\
|\%|\end{array}$ & C.V. & $\begin{array}{l}\text { Min. } \\
|\%|\end{array}$ & $\begin{array}{l}\text { Max. } \\
\text { (\%) }\end{array}$ & $\begin{array}{l}\text { Median } \\
(\%)\end{array}$ \\
\hline Anaheim, $C A^{a}$ & 10.7 & 14.6 & 1.36 & -23.4 & 28.5 & 14.1 \\
\hline Atlanta, GA & 19.1 & 6.5 & 0.34 & 9.5 & 32.1 & 17.8 \\
\hline Baltimore, MD & 10.1 & 7.2 & 0.71 & -0.9 & 22.7 & 9.3 \\
\hline Birmingham, AL & 14.6 & 6.7 & 0.46 & -3.5 & 24.2 & 14.3 \\
\hline Boston, MA & 12.2 & 20.6 & 1.69 & -28.3 & 40.6 & 18.0 \\
\hline Buffalo, NY & 7.5 & 9.2 & 1.22 & -6.4 & 24.8 & 4.6 \\
\hline Charlotte, NC & 16.9 & 5.4 & 0.32 & 5.1 & 25.5 & 18.2 \\
\hline Chicago, IL & 8.5 & 7.6 & 0.89 & -8.3 & 20.1 & 8.8 \\
\hline Cincinnati, OH & 8.5 & 8.0 & 0.94 & -11.5 & 17.4 & 11.2 \\
\hline Cleveland, $\mathrm{OH}$ & 9.6 & 10.0 & 1.04 & -13.0 & 18.5 & 15.1 \\
\hline Columbus, $\mathrm{OH}$ & 12.7 & 7.1 & 0.56 & -6.7 & 20.5 & 15.3 \\
\hline Dallas, TX & 6.1 & 14.7 & 2.40 & -23.5 & 32.3 & 9.1 \\
\hline Denver, CO & 8.6 & 17.4 & 2.03 & -22.8 & 30.5 & 14.2 \\
\hline Detroit, MI & 15.1 & 15.0 & 0.99 & -20.9 & 30.8 & 19.5 \\
\hline Fort Worth, TX & 11.7 & 12.0 & 1.03 & -9.7 & 35.0 & 12.9 \\
\hline Houston, TX & 11.4 & 12.9 & 1.14 & -27.4 & 28.9 & 13.6 \\
\hline Indianapolis, IN & 13.9 & 7.2 & 0.52 & -9.9 & 21.0 & 16.5 \\
\hline Kansas City, MO & 13.1 & 9.4 & 0.72 & -6.6 & 29.4 & 9.9 \\
\hline Los Angeles, $C A^{a}$ & 10.5 & 14.3 & 1.36 & -26.7 & 30.5 & 11.9 \\
\hline Memphis, TN & 16.3 & 0.3 & 0.39 & 2.3 & 26.2 & 15.4 \\
\hline Miami, $\mathrm{FL}^{\mathrm{a}}$ & 11.9 & 10.4 & 0.88 & -17.9 & 32.6 & 14.8 \\
\hline Milwaukee, W/ & 6.4 & 11.3 & 1.75 & -21.6 & 16.5 & 13.0 \\
\hline Minneapolis, MN & 9.9 & 9.0 & 0.91 & -6.1 & 28.9 & 7.8 \\
\hline New Orleans, LA & 8.4 & 17.2 & 2.04 & -24.9 & 28.4 & 14.5 \\
\hline New York, NY & 10.3 & 19.6 & 1.91 & -24.9 & 40.4 & 16.1 \\
\hline Newark, NJ & 8.0 & 17.0 & 2.12 & -26.8 & 37.4 & 12.9 \\
\hline Norfolk, VA & 15.2 & 4.5 & 0.29 & 7.4 & 28.0 & 15.1 \\
\hline Oklahoma City, OKa & 14.5 & 16.0 & 1.10 & -29.8 & 39.3 & 21.2 \\
\hline Philadelphia, PA & 12.1 & 11.0 & 0.91 & -6.3 & 30.5 & 11.0 \\
\hline Phoenix, AZ & 13.5 & 11.2 & 0.83 & -5.3 & 34.3 & 10.9 \\
\hline Pittsburgh, PA & 10.9 & 7.7 & 0.71 & -9.1 & 21.0 & 13.5 \\
\hline Portland, $O G$ & 10.7 & 16.4 & 1.54 & -22.8 & 29.4 & 17.2 \\
\hline Providence, RI & 8.4 & 18.2 & 2.18 & -28.6 & 39.2 & 9.7 \\
\hline Riverside, $C^{a}$ & 8.2 & 17.0 & 2.07 & -32.6 & 28.4 & 11.8 \\
\hline Sacramento, CA & 5.4 & 17.3 & 3.19 & -28.4 & 29.2 & 7.0 \\
\hline Salt Lake City, UT & 8.2 & 17.0 & 2.07 & -20.5 & 33.3 & 10.0 \\
\hline San Diego, CA & 5.3 & 16.2 & 3.06 & -24.2 & 28.6 & 6.8 \\
\hline San Francisco, $C^{a}$ & 10.5 & 16.6 & 1.58 & -28.1 & 32.2 & 11.6 \\
\hline Seattle, WA & 10.4 & 12.5 & 1.20 & -13.8 & 28.0 & 12.5 \\
\hline St. Louis, MO & 12.5 & 6.0 & 0.48 & -5.1 & 23.5 & 13.0 \\
\hline Tampa, FL & 19.9 & 6.8 & 0.34 & 6.5 & 36.1 & 18.0 \\
\hline Washington, DC & 8.9 & 10.7 & 1.20 & -8.6 & 25.7 & 7.4 \\
\hline U.S. & 13.9 & 5.4 & 0.39 & 4.1 & 24.7 & 13.6 \\
\hline
\end{tabular}

Notes: Returns are calculated for 77 5-year holding periods from 1978:Q1 to 2001:Q4 assuming 30-year, fixed rate loan, 80\% L/V ratio and 28\% tax rate. The source is Jud and Winkler, 2005.

aBecause the IRR model yields multiple solutions for some holding periods, the returns for Anaheim. Houston, Los Angeles, Miami, Oklahoma City, Riverside and San Francisco are computed with 65 , $65,63,76,64,70$ and 73 5-year holding periods respectively.
The level of risk also differs widely among MSAs: the coefficient of variation extends from a low of 0.29 in Norfolk to a high of 3.19 in Sacramento. The correlation between return and risk (standard deviation) among the forty-two MSAs in Exhibit 4 is not positive as might be expected; rather, the correlation is a -0.51 , which is significant at the 0.01 -level and above.

\section{Housing Markets and the Efficient Investment Frontier}

The determination of the efficient frontier is grounded in research by Markowitz (1952) and applied more recently by Brueckner (1997). Suppose that the expected rate of return for asset $i$ is defined as $E\left(R_{i}\right)$, and $w_{i}$ is the percentage weight attributable to the expected return on asset $i$. Then the expected occupancy rate for a portfolio of $N$ assets is defined as the weighted average of the individual expected rates of return for the $N$ assets as follows:

$$
E\left(R_{p}\right)=\sum_{i=1}^{N} w_{i} E\left(R_{i}\right)
$$

The portfolio variance is the weighed sum of variance and covariance of expected rate of return terms for all combinations of rates of return for assets $i$ and $j$ as follows:

$$
\operatorname{VAR}\left(R_{p}\right)=\sum_{i=1}^{N} \sum_{j=1}^{N} w_{i} w_{j} \sigma_{i j} .
$$

Where $\sigma_{i j}$ is the variance term when $i=j$ and the covariance term when $i \neq j ; w_{i}$ and $w_{j}$ are the percentages allocated to each asset $i$ and $j$.

The efficient set is the mean-variance choices of asset from the opportunity set of all assets, where for a given variance (or standard deviation), no other selection of opportunities offers a higher mean return. The weights for all assets are constrained to be such that $0 \leq w_{i} \leq 1$ and $\Sigma_{i=1}^{N} w_{i}=$ 1.0 ; no short-selling is permitted. The identification of the efficient sets requires the maximization of Equation (2) with respect to Equation (3), with constraints on $w_{i}$ as previously defined. ${ }^{12}$ 
Exhibit 5

Housing in an Efficient Investment Frontier

\begin{tabular}{|c|c|c|c|c|c|c|c|c|}
\hline \multirow{2}{*}{$\begin{array}{l}\text { Holding } \\
\text { Period } \\
\text { (yrs.) }\end{array}$} & \multirow[b]{2}{*}{$\begin{array}{l}\text { Tax Rate } \\
(\%)\end{array}$} & \multirow[b]{2}{*}{$\begin{array}{l}\mathrm{L} / \mathrm{V} \\
\text { Ratio }(\%)\end{array}$} & \multicolumn{3}{|c|}{ Allocation to Housing } & \multicolumn{3}{|c|}{ Allocation to Large Stocks } \\
\hline & & & $\begin{array}{l}\text { Minimum } \\
\text { Risk (\%) }\end{array}$ & $\begin{array}{l}\text { Median } \\
\text { Risk (\%) }\end{array}$ & $\begin{array}{l}\text { Maximum } \\
\text { Risk (\%) }\end{array}$ & $\begin{array}{l}\text { Minimum } \\
\text { Risk }(\%)\end{array}$ & $\begin{array}{l}\text { Median } \\
\text { Risk (\%) }\end{array}$ & $\begin{array}{l}\text { Maximum } \\
\text { Risk }(\%)\end{array}$ \\
\hline 10 & 28 & 0 & 72.1 & 35.6 & 0.0 & 27.9 & 63.9 & 100.0 \\
\hline 10 & 28 & 50 & 53.7 & 37.3 & 0.0 & 28.5 & 62.3 & 100.0 \\
\hline 10 & 28 & 80 & 32.4 & 37.0 & 0.0 & 27.6 & 39.5 & 100.0 \\
\hline 10 & 28 & 90 & 24.1 & 32.9 & 100.0 & 25.7 & 46.5 & 0.0 \\
\hline 10 & 15 & 0 & 72.2 & 34.7 & 0.0 & 27.8 & 63.5 & 100.0 \\
\hline 10 & 15 & 50 & 51.7 & 32.9 & 100.0 & 25.7 & 46.5 & 0.0 \\
\hline 10 & 15 & 80 & 30.0 & 24.5 & 0.0 & 27.9 & 57.3 & 100.0 \\
\hline 10 & 15 & 90 & 22.7 & 22.0 & 0.0 & 27.5 & 52.2 & 100.0 \\
\hline 5 & 28 & 0 & 12.2 & 11.1 & 0.0 & 1.9 & 32.2 & 100.0 \\
\hline 5 & 28 & 50 & 41.0 & 40.3 & 0.0 & 0.0 & 29.0 & 100.0 \\
\hline 5 & 28 & 80 & 19.7 & 31.5 & 0.0 & 1.5 & 10.7 & 100.0 \\
\hline 5 & 28 & 90 & 13.4 & 23.5 & 100.0 & 1.4 & 9.8 & 0.0 \\
\hline 5 & 15 & 0 & 77.9 & 36.5 & 0.0 & 0.0 & 41.5 & 100.0 \\
\hline 5 & 15 & 50 & 39.7 & 23.5 & 100.0 & 1.4 & 9.8 & 0.0 \\
\hline 5 & 15 & 80 & 18.8 & 16.6 & 0.0 & 0.9 & 31.7 & 100.0 \\
\hline 5 & 15 & 90 & 12.2 & 11.1 & 0.0 & 1.9 & 32.2 & 100.0 \\
\hline 3 & 28 & 0 & 60.4 & 40.5 & 0.0 & 0.0 & 34.5 & 100.0 \\
\hline 3 & 28 & 50 & 31.1 & 32.0 & 0.0 & 0.0 & 29.7 & 100.0 \\
\hline 3 & 28 & 80 & 18.8 & 8.7 & 0.0 & 15.5 & 45.4 & 100.0 \\
\hline 3 & 28 & 90 & 10.4 & 6.8 & 0.0 & 18.2 & 44.8 & 100.0 \\
\hline 3 & 15 & 0 & 60.4 & 38.2 & 0.0 & 0.0 & 35.1 & 100.0 \\
\hline 3 & 15 & 50 & 30.5 & 6.8 & 0.0 & 18.2 & 44.8 & 100.0 \\
\hline 3 & 15 & 80 & 13.7 & 11.3 & 0.0 & 0.0 & 29.4 & 100.0 \\
\hline 3 & 15 & 90 & 9.8 & 3.3 & 0.0 & 18.3 & 43.3 & 100.0 \\
\hline
\end{tabular}

Note: Optimization models utilize the Ibbotson data with return series that include S\&P 500 (large stocks), small stocks, long-term corporate bonds, long-term treasury bonds, intermediate-term treasury bonds, 90-day treasury bills and housing returns calculated by the authors.

Efficient sets were identified using the Ibbotson bonds; (5) intermediate-term treasury bonds; (6) quarterly data with return series that include: (1) 90-day Treasury bills; and (7) the housing returns S\&P 500 (large stocks); (2) small stocks; (3) long- series calculated by Jud and Winkler (2005). The term corporate bonds; (4) long-term Treasury results are shown in Exhibit 5.

Exhibit 6

Housing in an Efficient Investment Frontier

\begin{tabular}{|c|c|c|c|c|c|c|}
\hline \multirow[b]{2}{*}{ Metro Area } & \multicolumn{3}{|c|}{ Allocation to Housing } & \multicolumn{3}{|c|}{ Allocation to Large Stocks } \\
\hline & $\begin{array}{l}\text { Minimum } \\
\text { Risk }(\%)\end{array}$ & $\begin{array}{l}\text { Median } \\
\text { Risk (\%) }\end{array}$ & $\begin{array}{l}\text { Maximum } \\
\text { Risk }(\%)\end{array}$ & $\begin{array}{l}\text { Minimum } \\
\text { Risk (\%) }\end{array}$ & $\begin{array}{l}\text { Median } \\
\text { Risk (\%) }\end{array}$ & $\begin{array}{l}\text { Maximum } \\
\text { Risk (\%) }\end{array}$ \\
\hline Atlanta & 16.8 & 39.6 & 100.0 & 0.0 & 9.3 & 0.0 \\
\hline Boston & 0.0 & 0.0 & 0.0 & 16.8 & 46.1 & 100.0 \\
\hline Chicago & 21.4 & 19.7 & 0.0 & 0.0 & 29.9 & 100.0 \\
\hline Dallas & 1.7 & 0.2 & 0.0 & 14.8 & 46.0 & 100.0 \\
\hline San Diego & 0.0 & 0.3 & 0.0 & 16.7 & 45.9 & 100.0 \\
\hline
\end{tabular}

Note: Optimization models utilize the Ibbotson data with return series that include S\&P 500 (large stocks), small stocks, long-term corporate bonds, long-term treasury bonds, intermediate-term treasury bonds, 90-day treasury bills and housing returns calculated by the authors. The table assumes a $28 \%$ tax rate, 5 -year holding period and $80 \%$ loan-to-value ratio. 
Perusing Exhibit 5 reveals several important findings. First, there is a substantial allocation to housing in most of the minimum risk portfolios. Second, housing is not part of the allocation in the maximum risk portfolios, with a few notable exceptions. Third, the allocations to housing usually are greater in the higher tax bracket. Fourth, the housing allocations are lower for shorter holding periods.

The allocation to housing also was found to vary widely among MSAs. Exhibit 6 shows the optimum allocations for five MSAs (Atlanta, Boston, Chicago, Dallas, \& San Diego), assuming a 5-year holding period, $28 \%$ tax rate and an $80 \%$ loan-tovalue ratio. The allocation to housing in the minimum risk portfolios shown in Exhibit 6 ranges from $21.4 \%$ in Chicago to $0.0 \%$ in Boston and San Diego. The allocation to housing in the maximum risk portfolio is $100.0 \%$ in Atlanta, but $0.0 \%$ in the other four areas.

\section{Conclusion}

This paper examines the portfolio rate of return and risk of single-family housing investment nationally and at the MSA level. It is important to note that the analysis is based on the OFHEO index, which largely excludes the idiosyncratic risk associated with owning an individual house. The remaining risk would be analogous to a welldiversified limited housing partnership or a portfolio of residential rental housing.

We find that rates of return are higher for longer holding periods, while risk declines with longer holding periods. Higher leverage normally raises both the returns and risks of homeownership. The tax subsidy provided by the interest deduction combined with the use of higher leverage provides higher rates of return for individuals in higher tax brackets.

During the 1978:Q1-2001:Q4 period (assuming 5year holding periods and a $28 \%$ marginal tax rate), homeownership with high leverage provides returns greater than stocks, but with more risk. Nonleveraged homeownership provides returns that are about equal to intermediate treasuries, but with substantially lower risk.

Considered within the context of an investment portfolio, the advantage of homeownership arises because of its correlations with other assets. For large-cap stocks, all the correlations with homeownership are positive and all are statistically significant. For other financial assets, the correlations with homeownership are negative, except for the non-leveraged homeownership return series. For non-leveraged homeownership, the correlations that are statistically significant have a positive coefficient. Additionally, the correlation coefficients of inflation and homeownership returns are statistically insignificant in all cases.

The findings of this study are comparable with prior research. For the 1980-1997 time period, Eichholtz, Koedijk and de Roon (2002) find a positive correlation of residential property returns with stocks and a negative correlation with bonds. Flavin and Yamashita (2002) find a slight negative correlation of housing returns with T-bills, bonds and stocks; however, their measure of housing return is based on owners' estimates; returns are annual and exclude transaction costs. Goetzmann (1993) finds larger negative correlations with all three classes of securities; however, he suggests that high inflation and stagflation negatively affect stock and bond returns and that his results should not be generalized for future investment. In addition, these studies focus on annual returns instead of longer 3-, 5- and 10-year holding period returns.

We find that the average rate of return and risk to homeownership varies widely among the forty-two MSAs. Average returns range from a high of $19.9 \%$ in Tampa to a low of 5.3\% in San Diego during the 1978-2001 period, assuming a 5-year holding period, $80 \%$ leverage and a $28 \%$ tax rate. Goetzmann (1993) also finds considerable variation in 5-year housing returns over the 1971:Q2-1986:Q4 period for regional portfolios from four cities (Atlanta, Chicago, Dallas and San Francisco).

Optimum portfolios reported here were identified using the Ibbotson quarterly data with return series that include: (1) S\&P 500 (large stocks); (2) 
small stocks; (3) long-term corporate bonds; (4) long-term Treasury bonds; (5) intermediate-term Treasury bonds; (6) 90-day Treasury bills; and (7) the housing returns series calculated by the authors. The results suggest that (1) there is a substantial allocation to housing in most of the minimum risk portfolios; (2) housing generally is not part of the allocation in the maximum risk portfolios; (3) the allocations to housing usually are greater in higher tax brackets, particularly for high loan-to-value ratios; and (4) housing allocations are lower for shorter holding periods. Consistent with Flavin and Yamashita (2002), the use of leverage with homeownership has a dramatic impact on portfolio allocation; however, Flavin and Yamashita focused on life-cycle patterns at various ages so the results are not comparable.

The allocation to housing also was found to vary widely among MSAs. As anticipated, the allocation appears to be strongly related to the long-run returns in the particular MSA. High housing returns for Atlanta resulted in a $100 \%$ allocation for the maximum risk/return point, and also a relatively high weighting in the minimum and median risk portfolios. For other MSAs with lower returns, the maximum risk/return portfolio included a $100 \%$ allocation to stocks. Goetzmann (1993) suggests a $100 \%$ allocation to stocks based on a maximum risk/return position in all of the four MSAs included in his study (Atlanta, Chicago, Dallas and San Francisco).

The findings of this study demonstrate a great variation in housing returns based on length of holding period, tax rates and the use of leverage. The often low or negative correlation of residential housing returns with other financial securities suggests potentially large risk reduction benefits for holding residential housing. In many instances, housing is included in the minimum and median risk efficient frontiers, especially at low loan-tovalue ratios and for longer holding periods, while allocation to large stocks dominates the maximum risk position on the efficient frontier. Further research needs to explore the contribution of housing in particular MSAs to the performance of a diversified wealth portfolio over different holding periods.

\section{Endnotes}

1. Unsystematic risk is also called non-diversifiable or idiosyncratic risk. It is the risk attributable to holding an individual asset that is not influenced by general market factors. Markowitz (1952) developed the theory of reduction in unsystematic risk through portfolio diversification.

2. As early as the early 1990s, Shiller, Case and Weiss (1993) and later Shiller and Case (1996) suggested the establishment of futures and options markets to hedge real estate risk. The possibility of a housing futures market as a method to manage housing risk appears to be on the horizon. On December 6, 2004, the Chicago Merchantile Exchange and MACRO Securities Research announced a joint proposal to explore the development of futures contracts based on residential housing prices. The intent was to increase liquidity in new asset classes and to explore the development of derivatives based on the Fiserve (Shiller, Case and Weiss, 1993) family of housing price indexes. The timing also appears to be related the significant volatility in housing prices over the past twelve months relative to the past ten years.

3. In the simplest form, the limited partner's return would come from a portion of the sales price of the house; more complex arrangements could include cash flows occurring over the life of the partnership.

4. Although the housing indexes used in this study are based on very large repeated-sales samples, modern portfolio theory indicates that a portfolio with as few as ten or twelve assets has mainly systematic risk and only a small amount of non-diversifiable risk. Therefore, the findings of this study could be applicable to reasonably small housing portfolios.

5. The investment returns approach taken in this study is from the perspective of a portfolio of single-family, owneroccupied residences. Rental housing provides very similar cash flows (see Endnote 6), therefore, the findings of this study can be extended to the residential rental market. From a viewpoint of the described prospective financial innovations in housing risk management, it appears similar to the sharing of revenues and expenses by limited partners in a limited housing partnership. In a housing futures market, it is likely to be based on housing price indexes, which exclude other parts of the return calculation. However, it is not possible to precisely identify the cash flow equation that would be used for an analysis of returns of a housing partnership because this product, as with housing futures, does not currently exist.

6. In the case of rental income, the imputed rent would be actual rent, and therefore, would be taxable. However, rental housing can be depreciated and maintenance and insurance expenses are tax deductible. Using the data for this study, the imputed rent is $7.7 \%$ and maintenance and insurance costs are $0.72 \%$. Depreciation is a non-cash expense, but can be applied to residential rental income property assuming a 27.5-year depreciation period or $3.64 \%$ per year. Therefore, the differential between imputed rent and depreciation, maintenance costs and insurance expenses is $3.34 \%$. At a $28 \%$ marginal tax rate, this rate of return differential due to taxes is $0.94 \%$; at a $15 \%$ marginal tax rate, the tax differential is $0.5 \%$. This discrepancy is insignificant for the purpose of this analysis. However, there is a 
capital gain on the sale of rental housing; this is often avoidable for owner-occupied residences.

7. The cash flow assumptions used for this analysis assume an owner-occupied perspective. Rental properties or housing limited partnership cash flows might differ to some extent. For example, rental properties may have different leverage and actual rents (instead of imputed) may be taxable. For housing limited partnerships, the question of ongoing rent to the partnership, payment of interest and expenses would depend upon the particular contract. Therefore, we take the investment perspective of owner-occupied housing. However, the findings should provide insight to other potential investors in single-family housing.

8. Property taxes do vary substantially across MSAs; however, we use an average because of the complexities inherent in estimating different property taxes across MSAs.

9. Frew and Jud (1987) find that selling commissions are approximately evenly split between the buyer and seller because the seller receives a higher price than in the absence of a real estate agent. Harney (2004) reports that average residential sales commission rates are $5.06 \%$.

10. A short holding period does not provide much price appreciation to overcome the initial fees and sales commission charges; in addition, the low marginal tax rate offers a small tax shield.

11. A decrease in interest rates increases refinancing activity and reduces interest charges, resulting in increased annual cash flow and higher holding period returns.

12. The efficient sets were identified using MATLAB ${ }^{\circledR} 5$ with the Statistics, Finance and Optimization Toolboxes.

\section{References}

Alberts, W. W. and H. S. Kerr, The Rate of Return from Investing in Single-Family Housing, Land Economics, 1981, $57: 2,230-42$.

Brueckner, J. K., Consumption and Investment Motives and the Portfolio Choices of Homeowners, Journal of Real Estate Finance and Economics, 1997, 12:2, 9-180.

Caplin, A., Household Asset Portfolios and the Reform of the Housing Finance Market, TIAA-CREF Research Dialogues, 1999, No. 59, 1-12.

Caplin, A., C. Sewin, C. Freeman and J. Tracy, Housing Partnerships, Cambridge, MA: MIT Press, 1997.

Case, K. and R. Shiller, Forecasting Prices and Excess Returns in the Housing Market, Journal of the American Real Estate and Urban Economics Association, 1990, 18:3, 253-73.

Coyne, T. J., W. M. Goulet and M. J. Picconi, Residential Real Estate versus Financial Assets, Journal of Portfolio Management, 1980, 7:1, 20-4.
Eichholtz, P. M., K. G. Koedijk and F. de Roon, The Portfolio Implications of Home Ownership, Working paper, Maastricht University and University of Amsterdam, 2002.

Englund, P., M. Hwang and J. M. Quigley, Hedging Housing Risk, Journal of Real Estate Finance and Economics, 2002, $24: 1 / 2,167-200$.

Ermer, C. M., S. M. Cassidy and M. J. Sullivan, Modeling Returns to Owner-Occupied Single-Family Residences, Journal of Economics and Finance, 1994, 18:2, 205-17.

Flavin, M. and T. Yamashita, Owner-Occupied Housing and the Composition of the Household Portfolio, American Economic Review, 2002, 92:1, 345-62.

Frew, J. R. and G. D. Jud, Who Pays the Real Estate Broker's Commission?, Greenwich, Conn. and London: JAI Press (Research in Law and Economics Series 10, 1987, 177-87.

Goetzmann, W. N., The Single Family Home in the Investment Portfolio, Journal of Real Estate Finance and Economics, 1993, 6:3, 201-22.

Harney, K. R., Data Show Commission Rates for U.S. Sales by Region, San Diego Union-Tribune, July 25, 2004.

Harris, J., Investment Performance of Owner-Occupied Housing, Paper presented at the American Real Estate Society Conference, April 2002.

Hendershott, P. H. and S. C. Hu., Inflation and Extraordinary Returns on Owner-Occupied Housing: Some Implications for Capital Allocation and Growth, Journal of Macroeconomics 1981, 3:2, 177-203.

Jud, G. D. and D. T. Winkler, Returns to Single-Family OwnerOccupied Housing, Journal of Real Estate Practice and Education, 2005, 8:1, 25-44.

Markowitz, H., Portfolio Selection, Journal of Finance, 1952, 7:1, 77-91.

Miller, N. G. and M. A. Sklarz., A Comment on "Tax Rates and Implicit Rates of Return on Owner-Occupied Single-family Housing," Journal of Real Estate Research. 1989, 4:1, 81-4.

Peiser, R. B. and L. B. Smith, Homeownership Returns, Tenure Choice and Inflation, Journal of the American Real Estate and Urban Economics Association, 1985, 13:4, 343-60.

Shiller, R. and K. E. Case, Mortgage Default Risk and Real Estate Prices: The Use of Index-Based Futures and Options in Real Estate, Journal of Housing Research, 1996, 7:2, 243-58.

Shiller, R., K. E. Case and A. N. Weiss, Index-Based Futures and Options Trading in Real Estate, Journal of Portfolio Management, 1993, Winter, 83-92.

Webb, J. R. and J. H. Rubens, Tax Rates and Implicit Rates of Return on Owner-Occupied Single-Family Housing, Journal of Real Estate Research, 1987, 2:2, 11-28. 
Copyright of Journal of Real Estate Portfolio Management is the property of American Real Estate Society and its content may not be copied or emailed to multiple sites or posted to a listserv without the copyright holder's express written permission. However, users may print. download, or email articles for individual use. 